\title{
Variability in terrigenous sediment supply offshore of the Río de la Plata (Uruguay) recording the continental climatic history over the past 1200 years
}

\author{
Laura Perez $^{1,4}$, Felipe García-Rodríguez ${ }^{1,4}$, and Till J. J. Hanebuth ${ }^{2,3}$ \\ ${ }^{1}$ Sección Oceanología, Facultad de Ciencias, Universidad de la República, Iguá 4225, Montevideo 11400, Uruguay \\ ${ }^{2}$ School of Coastal and Marine Systems Sciences, Coastal Carolina University, SC 29528, USA \\ ${ }^{3}$ MARUM, Center for Marine Environmental Sciences, University of Bremen, Leobener Straße, 28359 Bremen, Germany \\ ${ }^{4}$ Centro Universitario Regional Este, CURE-Rocha, Ruta 9 intersección Ruta 15, Rocha, Uruguay
}

Correspondence to: Laura Perez (1p3_3@hotmail.com)

Received: 10 March 2015 - Published in Clim. Past Discuss.: 14 April 2015

Revised: 26 January 2016 - Accepted: 13 February 2016 - Published: 14 March 2016

\begin{abstract}
The continental shelf adjacent to the Río de la Plata (RdlP) exhibits extremely complex hydrographic and ecological characteristics which are of great socioeconomic importance. Since the long-term environmental variations related to the atmospheric (wind fields), hydrologic (freshwater plume), and oceanographic (currents and fronts) regimes are little known, the aim of this study is to reconstruct the changes in the terrigenous input into the inner continental shelf during the late Holocene period (associated with the RdlP sediment discharge) and to unravel the climatic forcing mechanisms behind them. To achieve this, we retrieved a $10 \mathrm{~m}$ long sediment core from the RdlP mud depocenter at $57 \mathrm{~m}$ water depth (GeoB 13813-4). The radiocarbon age control indicated an extremely high sedimentation rate of $0.8 \mathrm{~cm}$ per year, encompassing the past 1200 years (AD 750-2000). We used element ratios ( $\mathrm{Ti} / \mathrm{Ca}, \mathrm{Fe} / \mathrm{Ca}$, $\mathrm{Ti} / \mathrm{Al}, \mathrm{Fe} / \mathrm{K}$ ) as regional proxies for the fluvial input signal and the variations in relative abundance of salinity-indicative diatom groups (freshwater versus marine-brackish) to assess the variability in terrigenous freshwater and sediment discharges. $\mathrm{Ti} / \mathrm{Ca}, \mathrm{Fe} / \mathrm{Ca}, \mathrm{Ti} / \mathrm{Al}, \mathrm{Fe} / \mathrm{K}$ and the freshwater diatom group showed the lowest values between AD 850 and 1300, while the highest values occurred between AD 1300 and 1850.
\end{abstract}

The variations in the sedimentary record can be attributed to the Medieval Climatic Anomaly (MCA) and the Little Ice Age (LIA), both of which had a significant impact on rainfall and wind patterns over the region. During the MCA, a weakening of the South American summer monsoon system (SAMS) and the South Atlantic Convergence Zone (SACZ), could explain the lowest element ratios (indicative of a lower terrigenous input) and a marine-dominated diatom record, both indicative of a reduced RdlP freshwater plume. In contrast, during the LIA, a strengthening of SAMS and SACZ may have led to an expansion of the RdlP river plume to the far north, as indicated by higher element ratios and a marked freshwater diatom signal. Furthermore, a possible multidecadal oscillation probably associated with Atlantic Multidecadal Oscillation (AMO) since AD 1300 reflects the variability in both the SAMS and SACZ systems.

\section{Introduction}

The Río de la Plata (RdlP) estuary is fed by the Paraná and the Uruguay rivers and drains into the southwestern Atlantic Ocean (SWAO), forming the second largest estuary system in South America (Bisbal, 1995; Acha et al., 2003). The RdlP is the main source of continental freshwater and sediments entering the SWAO (Piola et al., 2008; Krastel et al., 2011, 2012; Razik et al., 2013; Lantzsch et al., 2014; Nagai et al., 2014). In this sense, the RdlP provides an average annual suspended sediment load of $79.8 \times 10^{6} \mathrm{t} \mathrm{yr}^{-1}$ (Depetris et al., 2003). Most of this discharge is directed close to the Uruguayan coast towards the inner continental shelf (Depetris et al., 2003; Gilberto et al., 2004). The RdlP freshwater discharge leads to a low-salinity plume on the inner continen- 
tal shelf, which can reach northerly areas up to $28^{\circ} \mathrm{S}$ (Piola et al., 2000). The low-salinity waters on the inner part of the continental shelf extend downwards to a depth of approximately $50 \mathrm{~m}$, while the outer part of the continental shelf (from 50 to $200 \mathrm{~m}$ ) is influenced by the Subtropical Confluence, where the warm, salty southward-flowing Brazil Current collides with the cold and less salty northward-flowing Malvinas Current (Piola et al., 2000).

The Paraná River contributes about $73 \%$ to the total RdlP freshwater discharge, and maximum values are found during austral summer (Depetris and Pasquini, 2007). This precipitation and river discharge pattern is associated with the southward expansion and intensification of the South American summer monsoon system (SAMS; Zhou and Lau, 1998; Chiessi et al., 2009). The SAMS is known to be a poleward displacement of the Intertropical Convergence Zone (ITCZ), and it is associated with a wet season that begins in the equatorial Amazon and propagates rapidly eastward and southeastward during austral spring (García and Kayano, 2010). The SAMS is closely associated with the South Atlantic Convergence Zone (SACZ; Carvalho et al., 2004), which is a main component of the SAMS (Nogués-Paegle et al., 2002; Almeida et al., 2007). The SACZ is an elongated NWSE band of convective activity that originates in the Amazon Basin, which extends above the northern RdlP drainage basin, and has its southernmost limit in the adjacent SWAO (Carvalho et al., 2004). Thus, the Paraná River discharge is largely determined by the SACZ (Robertson and Mechoso, 2000).

The RdlP is an extremely dynamic system which exhibits complex hydrodynamic features associated with the climatic pattern that affect the wind and oceanographic systems, as well as the river discharge (Piola et al., 2008). As mentioned above, a natural intra-annual variability exists with a higher river discharge during the summer season (Depetris and Pasquini, 2007). In addition, a northerly wind pattern during summer leads to a southward and offshore displacement of the low-salinity RdIP freshwater plume (Guerrero et al., 1997; Möller et al., 2008; Piola et al., 2008). In contrast, during the winter season, a lower RdlP discharge existed, but a predominant southerly wind pattern exists (associated with a northward displacement of the Westerlies). This situation forces a northward displacement of the RdlP plume and thus considerably diminishes the salinity on the southern Brazilian continental shelf (Guerrero et al., 1997; Camilloni, 2005; Möller et al., 2008; Piola et al., 2008).

The regional climatic system also exhibits an interannual and interdecadal variability, associated with environmental changes (expressed mainly in precipitation patterns) related to the El Niño-Southern Oscillation (ENSO) and the Pacific Decadal Oscillation (PDO), respectively (Depetris and Kempe, 1990; Depetris et al., 2003; Depetris and Pasquini, 2007; Garreaud et al., 2009; Barreiro, 2010). PDO is associated with ENSO as both seem to produce similar climatic effects, though their mechanisms are not yet fully under- stood (Garreaud et al., 2009). In this sense, it has been suggested that, during both the warm El Niño and the positive PDO phases, there is an increasing trend in precipitations over the RdlP drainage basin associated with an intensification of the SAMS, which leads to a higher RdIP river discharge, while the opposite trend was observed for the negative phases (Ciotti et al., 1995; Depetris and Pasquini, 2007; Garreaud et al., 2009; Barreiro, 2010; García-Rodríguez et al., 2014). However, Piola et al. (2005) reported strong NE winds during El Niño conditions which compensate for the effect of the positive precipitation anomalies, and thus prevent an anomalous northeastward displacement of the RdlP plume. In addition, there is evidence that the interannual variability in the RdlP drainage basin has a stronger influence on the Uruguay River discharge, while the decadal variability is most pronounced in the Paraná River supply (Robertson and Mechoso, 2000). Furthermore, Chiessi et al. (2009) published evidence that the Atlantic Multidecadal Oscillation (AMO) influences SAMS intensity on multidecadal timescales, leading to reduced/increased SAMS intensity when the AMO is in its positive/negative phase (Chiessi et al., 2009; Apaéstegui et al., 2014).

Regarding the late Holocene period, a significant number of studies have described the climatic history of South America over the last $1500 \mathrm{cal} \mathrm{yr} \mathrm{BP} \mathrm{(calibrated} \mathrm{thousands} \mathrm{of} \mathrm{years}$ before present), e.g., the Medieval Climatic Anomaly (MCA, AD 800-1300) and the Little Ice Age (LIA, AD 1400-1800; Cioccale, 1999; Iriondo, 1999; Piovano et al., 2009; Bird et al., 2011b; del Puerto et al., 2011, 2013; Vuille et al., 2012; Apaéstegui et al., 2014; Salvatecci et al., 2014). These climatic changes have affected the precipitation pattern over South America, with regional differences. For eastern Uruguay, this means a warmer and more humid pulse during the MCA, while in the LIA, a drier and colder climate was recorded (del Puerto et al., 2013). Piovano et al. (2009) inferred similar climatic conditions for the northeastern region of Argentina. In contrast, the opposite pattern was reported for southern Chile and Argentina, where a dry period occurred during the MCA, and a wetter pulse governed the LIA (Haberzettl et al., 2005). Furthermore, Vuille et al. (2012) reported similar conditions to those in Haberzettl et al. (2005) for southeastern Brazil.

Nevertheless, little is known about how the natural climatic variability over South America affects sedimentation, salinity and river discharge on the continental shelf in front of the RdlP during the late Holocene period (Burone et al., 2012; Perez et al., 2016). The aim of this study is therefore to determine the variations in the terrigenous sediment input into the ocean over the last $1200 \mathrm{cal} \mathrm{yr} \mathrm{BP}$. To determine how the continental influence competed with the marine regime, a $10 \mathrm{~m}$ long sediment core was taken from a confined mud depocenter on the inner Uruguayan continental shelf (GeoB 13813-4, Fig. 1). The sedimentary succession of this core was analyzed for major chemical elements $(\mathrm{Ca}$, $\mathrm{Ti}, \mathrm{Al}, \mathrm{Fe}$, and $\mathrm{K}$ ) and compared with previously published 


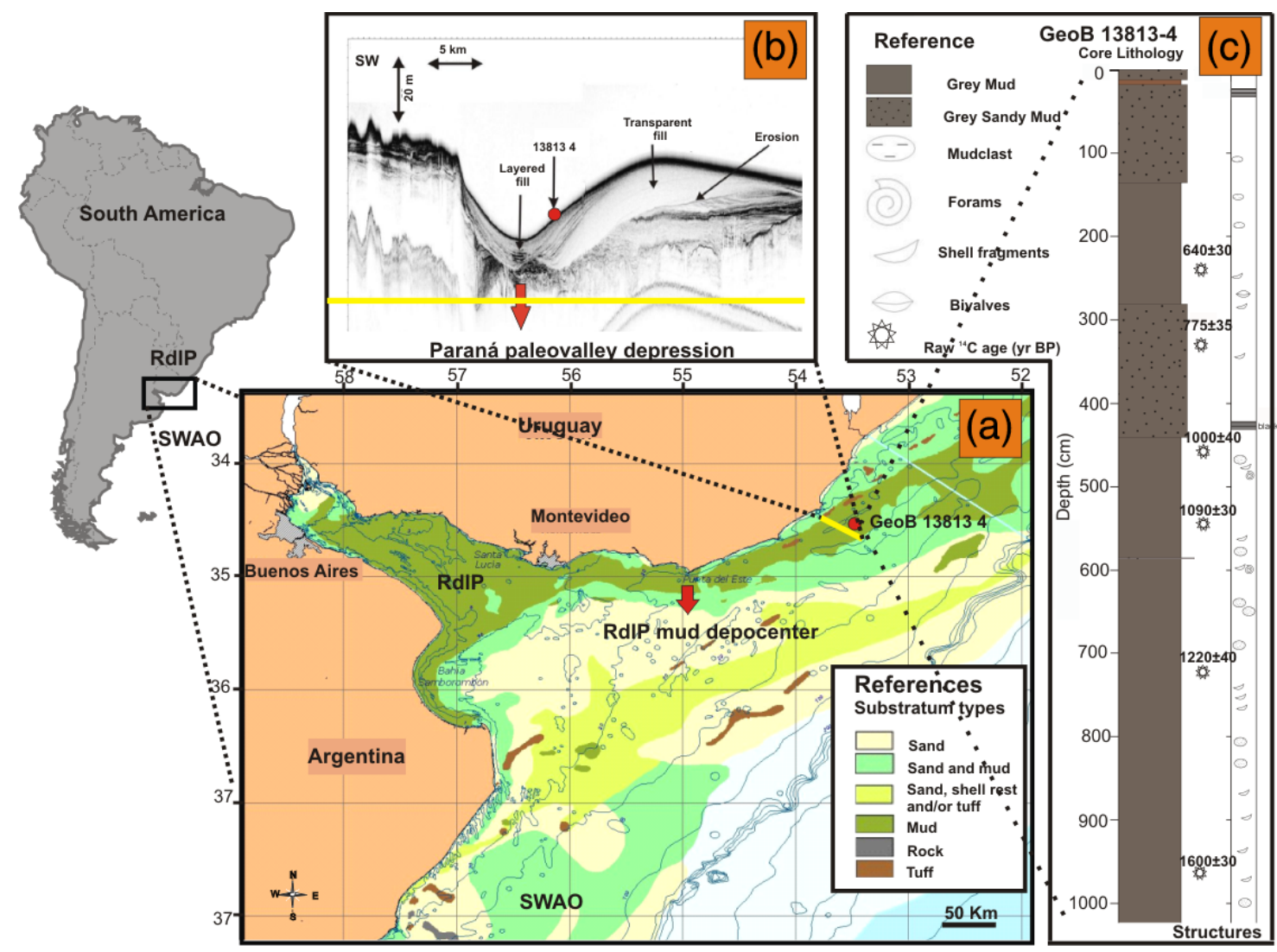

Figure 1. (a) Study area: the red circle indicates the location of Core GeoB 13813-4 retrieved from the inner-shelf mud depocenter off the Uruguayan coast (modified from Freplata, 2004). (b) Río de la Plata (RdlP) mud depocenter (Parasound sub-bottom profile), which represents the RdlP paleovalley and its sedimentary multi-story filling succession. (c) GeoB 13813-4 core lithology (b and $\mathbf{c}$ modified from Krastel et al., 2012, and Lantzsch et al., 2014). Stars on the right of the sediment core indicate ${ }^{14} \mathrm{C}$-dated intervals.

data of the diatom salinity-indicative groups, i.e., freshwater (F) and marine/marine-brackish (M-B; Perez et al., 2016), in order to assess variations in continental influence.

\section{Study area}

The study area is located on the Uruguayan inner continental shelf hosting the RdlP mud depocenter ( $50 \mathrm{~m}$ water depth, Fig. 1a, b). This silty clay depocenter (Martins and Urien, 2004; Lantzsch et al., 2014) is the result of regional paleogeographic evolution and is associated with deposits of fluvial origin (Urien and Ewing, 1974). The depocenter built up inside the RdlP paleovalley, which was incised by the paleoParaná River during lower sea levels (Masello and Menafra, 1998; Martins et al., 2003; Lantzsch et al., 2014; Hanebuth et al., 2016). The RdlP paleovalley depression offers an effective protection against the generally strong hydrodynamic conditions on the shelf, thus favoring the deposition and preservation of these muds (Fig. 1b).

\section{Materials and methods}

A $1028 \mathrm{~cm}$ long sediment core (GeoB 13813-4) was taken from the RdlP mud depocenter $\left(34^{\circ} 44^{\prime} 13^{\prime \prime} \mathrm{S}, 53^{\circ} 33^{\prime} 16^{\prime \prime} \mathrm{W}\right)$ during research cruise M76/3a with the German research vessel Meteor in July 2009 (Krastel et al., 2012; Fig. 1a). During this expedition, sub-bottom profiling with the shipboard Parasound system $(4 \mathrm{kHz})$ showed an elongated depression on the seafloor corresponding to the RdlP paleovalley filled with a complex pattern of acoustic facies (Fig. 1b; Krastel et al., 2012; Lantzsch et al., 2014).

\subsection{Age-depth model and sedimentation rates}

Material from bivalve shells collected from six sediment samples, distributed evenly over the core and preserved in life position, was used for radiocarbon dating $\left({ }^{14} \mathrm{C}\right.$, Table 1 ; Lantzsch et al., 2014; Perez et al., 2016). The samples were analyzed using AMS $-{ }^{14} \mathrm{C}$ (accelerated mass spectrometry) at the Poznan Radiocarbon Laboratory in Poland. The agedepth model used for the present study was then generated by using the free software Bacon (Blaauw and Christen, 2011; 
Fig. 2). The raw ${ }^{14} \mathrm{C}$ dates were calibrated using the calibration curve Marine13 (Reimer et al., 2013; cc=2) integrated into this program, and the weighted average ages are expressed in Table 1 (Blaauw and Christen, 2011). The standard reservoir age of 405 years was applied during calibration due to a lack of regional data, although intense water mixing and coastal upwelling in shallow waters might lead to significant differences in reservoir age (Reimer et al., 2013).

Bacon software is an approach for developing an agedepth model that uses Bayesian statistics to reconstruct Bayesian accumulation histories for sedimentary deposits. Bacon divides a sediment core into vertical sections $(5 \mathrm{~cm}$ thick), and estimates the sedimentation rate (years $\mathrm{cm}^{-1}$ ) for each section through millions of Markov chain Monte Carlo (MCMC) iterations.

\subsection{Paleoenvironmental proxies}

The two methodological approaches combined in this study were chosen according to previous successful applications for inferring continental versus marine influences in the Atlantic Ocean (Romero et al., 1999; Chiessi et al., 2009; Mahiques et al., 2009; Govin et al., 2012; Burone et al., 2013; Perez et al., 2016), as indicated below.

\subsubsection{Runoff-indicative element ratios}

The relative concentrations (expressed in counts per second, cps) of the major chemical elements used in this study $(\mathrm{Ca}$, $\mathrm{Ti}, \mathrm{Fe}, \mathrm{K}, \mathrm{Al}$ ) were obtained by an X-ray fluorescent (XRF) sediment core scanner AVAATECH at MARUM, University of Bremen. XRF core scanning is a fast, non-destructive technique which allows for the detection of a large number of chemical elements (Löwemark et al., 2011). This technique does not measure absolute element concentrations but instead relative intensities. As a consequence, the intensities of the elements are influenced by numerous factors such as water content and sediment density, organic matter content, grain size, biogenic contributions, and carbonate dissolution (Weltje and Tjallingii, 2008). For these reasons, it is unwise to use single element intensities, and it is more appropriate to use element ratios to normalize the data (Weltje and Tjallingii, 2008; Francus et al., 2009; Govin et al., 2012). Core GeoB 13813-4 was scanned in $1 \mathrm{~cm}$ steps throughout, and the $\mathrm{Ti} / \mathrm{Ca}, \mathrm{Fe} / \mathrm{Ca}, \mathrm{Fe} / \mathrm{K}$ and $\mathrm{Ti} / \mathrm{Al}$ element ratios were used.

$\mathrm{Ti}, \mathrm{Fe}$ and $\mathrm{Al}$ are elements related to aluminum/silicates, and are associated with clay minerals carried from the continent as weathering products, and through river discharge, they enter into the ocean (Goldberg and Arrhenius, 1958; Jansen et al., 1998; Yarincik et al., 2000). Therefore these elements vary with the terrigenous portion in offshore sediment (Martins et al., 2007; Burone et al., 2013). Most of the $\mathrm{K}$ in marine sediments is also associated with terrigenous materials (Goldberg and Arrhenius, 1958), and it oc- curs mainly in fully arid regions where chemical weathering rates are lower (Govin et al., 2012). In contrast, Ca mainly reflects the marine carbonate content in the sediment, and is thus associated with the local marine productivity (Haug et al., 2001; Salazar et al., 2004; Gonzalez-Mora and Sierro, 2007). Al, Ti and $\mathrm{K}$ are little affected by biological and redox variations, while $\mathrm{Fe}$ is sometimes altered by redox processes (Jansen et al., 1998; Yarincik et al., 2000; Löwemark et al., 2011). Burone et al. (2013) recorded a decreasing seaward gradient in $\mathrm{Ti}, \mathrm{Fe}$, and $\mathrm{Al}$ from a surface sediment transect from the inner RdlP off to the shelf. In addition, they observed the opposite trend for $\mathrm{Ca}$.

Numerous studies have used major elements in marine sediments to reconstruct climatic history, but the choice of particular element ratios and the interpretation of such proxies vary from site to site (Govin et al., 2012). Ti / Ca and $\mathrm{Fe} / \mathrm{Ca}$ ratios were widely used to reconstruct the continental versus the marine influence in the SWAO region (Chiessi et al., 2009; Mahiques et al., 2009; Govin et al., 2012; Bender et al., 2013; Burone et al., 2013). On the other hand, $\mathrm{Fe} / \mathrm{K}$ and $\mathrm{Ti} / \mathrm{Al}$ ratios were used in South America to reflect the degree of chemical weathering in areas without significant eolian input (Govin et al., 2012), such as the case of the RdlP (Mahowald et al., 2006). As a consequence of the above, we used element ratios $(\mathrm{Ti} / \mathrm{Ca}, \mathrm{Fe} / \mathrm{Ca}, \mathrm{Ti} / \mathrm{Al}$, $\mathrm{Fe} / \mathrm{K}$ ) as regional proxies for the fluvial input signal on the inner Uruguayan continental shelf.

\subsubsection{Salinity-indicative diatom groups}

Samples for diatom analyses were first chemically treated (with the aim of cleaning the material from carbonates, organic matter and clay particles) as explained in Perez et al. (2016). Diatom samples were first treated with $\mathrm{Na}_{2} \mathrm{P}_{2} \mathrm{O}_{7}$ to deflocculate the sediment and eliminate clay particles. The samples were then treated with $35 \% \mathrm{HCl}$ to remove inorganic carbonate material. Finally, the samples were boiled in $30 \% \mathrm{H}_{2} \mathrm{O}_{2}$ for $2 \mathrm{~h}$ to eliminate organic matter (Metzeltin and García-Rodríguez, 2003). Between each treatment, samples were rinsed at least four times with distilled water. Permanent sediment slides were mounted using the Entellan ${ }^{\circledR}$ mounting medium. A minimum of 400 valves were counted on each slide with a light microscope at $1250 \times$ magnification. The diatoms were then identified and counted at $10 \mathrm{~cm}$ depth intervals throughout the sediment core and in $1 \mathrm{~cm}$ steps within the uppermost $100 \mathrm{~cm}$ (Perez et al., 2016). Diatom species were identified and separated into two groups according to their ecological salinity preference, i.e., in groups indicating freshwater $(\mathrm{F})$ and marine/marine-brackish (M-B) conditions, according to Frenguelli (1941, 1945), Müller-Melchers (1945, 1953, 1959), Hasle and Syversten (1996), Witkowski et al. (2000), Metzeltin and GarcíaRodriguez (2003), Metzeltin et al. (2005), Hassan (2010), Sar et al. (2010) and other standard diatom literature (Perez et al., 2016). 
Table 1. Radiocarbon dates as obtained from the Bacon modeling.

\begin{tabular}{|c|c|c|c|c|c|}
\hline $\begin{array}{l}\text { Lab no. } \\
\text { (Poznan) }\end{array}$ & $\begin{array}{r}\text { Depth in core } \\
(\mathrm{cm})\end{array}$ & $\begin{array}{r}\text { Raw }{ }^{14} \mathrm{C} \text { age } \\
(\mathrm{yr} \mathrm{BP})\end{array}$ & $\begin{array}{r}\text { Bacon weighted average } \\
\text { age (cal yr BP) }\end{array}$ & $\begin{array}{r}\text { Bacon weighted average } \\
\text { age (cal yr AD) }\end{array}$ & $\begin{array}{l}\text { Sedimentation } \\
\text { rate }\left(\mathrm{cm} \mathrm{yr}^{-1}\right)\end{array}$ \\
\hline 35198 & 255 & $640 \pm 30$ & 230 & 1688 & 0.72 \\
\hline 47935 & 305 & $775 \pm 35$ & 371 & 1494 & 0.68 \\
\hline 42428 & 447 & $1000 \pm 40$ & 552 & 1293 & 0.78 \\
\hline 35199 & 560 & $1090 \pm 30$ & 665 & 1167 & 1.00 \\
\hline 47937 & 705 & $1220 \pm 40$ & 830 & 994 & 0.88 \\
\hline 42429 & 964 & $1600 \pm 30$ & 1197 & 753 & 0.70 \\
\hline
\end{tabular}
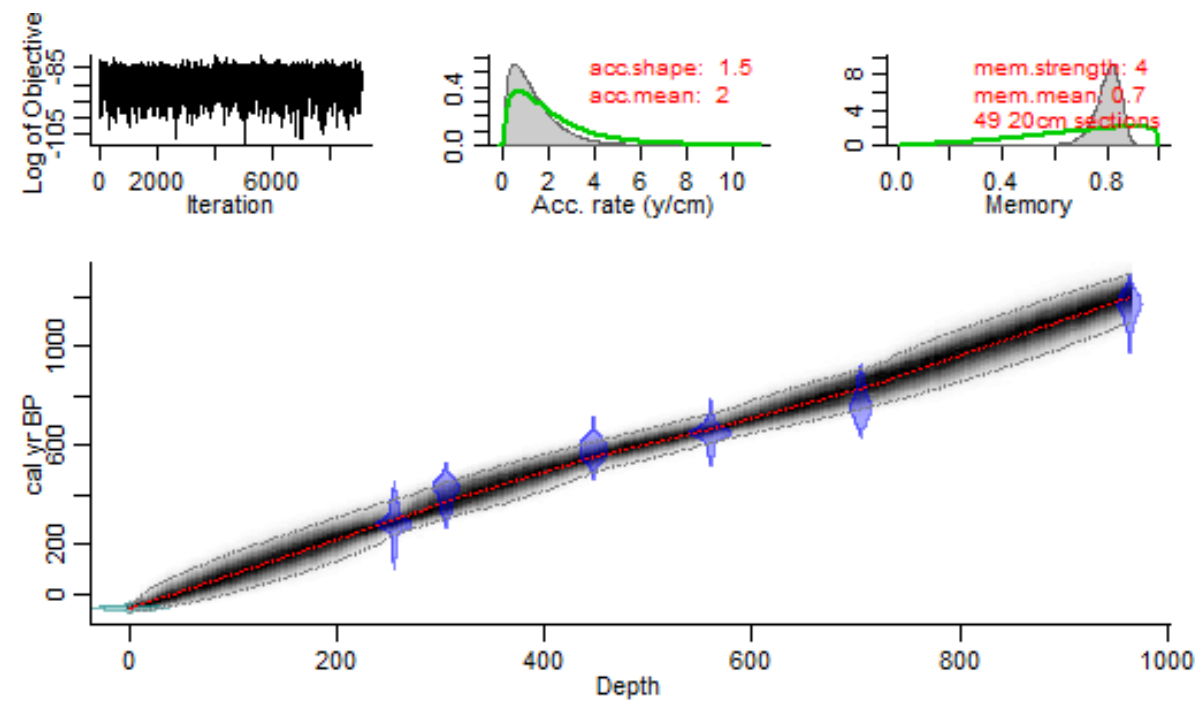

Figure 2. The age-depth model for core GeoB 13813-4 using the program Bacon. Upper panels depict the Markov chain Monte Carlo (MCMC) iterations (left), the prior (green curves) and posterior (grey histograms) distributions for the sedimentation rate (middle panel) and memory (right panel). The bottom panel shows the calibrated ${ }^{14} \mathrm{C}$ dates (transparent blue), extraction year of the core $(-59 \mathrm{yr} \mathrm{BP}, \mathrm{AD} 2009$, transparent light blue) and the age-depth model (grey stippled lines indicate the $95 \%$ confidence intervals; the red curve shows the "best" fit based on the weighted mean age for each depth).

Romero et al. (1999) determined variations in the continental water discharge by using freshwater diatoms (especially from the genus Aulacoseira) along a sediment surface transect from the eastern South Atlantic coast to the open ocean. The same approach was also used in this study to evaluate the freshwater influx on the inner continental shelf.

\section{Results}

\subsection{Age-depth model and sedimentation rates}

The core's base was dated to 1200 cal yr BP (AD 750), while a sample at $255 \mathrm{~cm}$ was dated to $230 \mathrm{cal}$ yr BP (AD 1700, Table 1). The sedimentation rate varied between 0.68 and $1.0 \mathrm{~cm} \mathrm{yr}^{-1}$, with a mean sedimentation rate of $0.8 \mathrm{~cm} \mathrm{yr}^{-1}$. Minimum values were observed in the top section (i.e., at 200 to $350 \mathrm{~cm}$ ) and in the bottom section (i.e., at 705 to $967 \mathrm{~cm}$ ), while the highest values were observed in the middle of the core (at 500 to $705 \mathrm{~cm}$; Perez et al., 2016).

\subsection{Paleoenvironmental proxies}

\subsubsection{Runoff-indicative element ratios}

All element ratios $(\mathrm{Ti} / \mathrm{Al}, \mathrm{Fe} / \mathrm{K}, \mathrm{Ti} / \mathrm{Ca}$ and $\mathrm{Fe} / \mathrm{Ca}$ ) showed similar profiles (Fig. 3). The lowest values were recorded between AD 850 and 1300 (coinciding with the MCA), and remained stable during this interval of time. In contrast, high values were recorded from AD 1300 to 1850 (associated with the LIA) and showed a high variability with a number of sharp maxima. In that sense, for the $\mathrm{Ti} / \mathrm{Al}$ and $\mathrm{Fe} / \mathrm{K}$ ratios, we recorded a succession of peaks and lows approximately every 100 years (from AD 1300 to 1500) and every 50 years (AD 1500 up to the present, Fig. 3). Moreover, during the last century, all element ratios showed a rapid increase toward the highest measured values, most pronounced over the last 50 years (Fig. 3). 


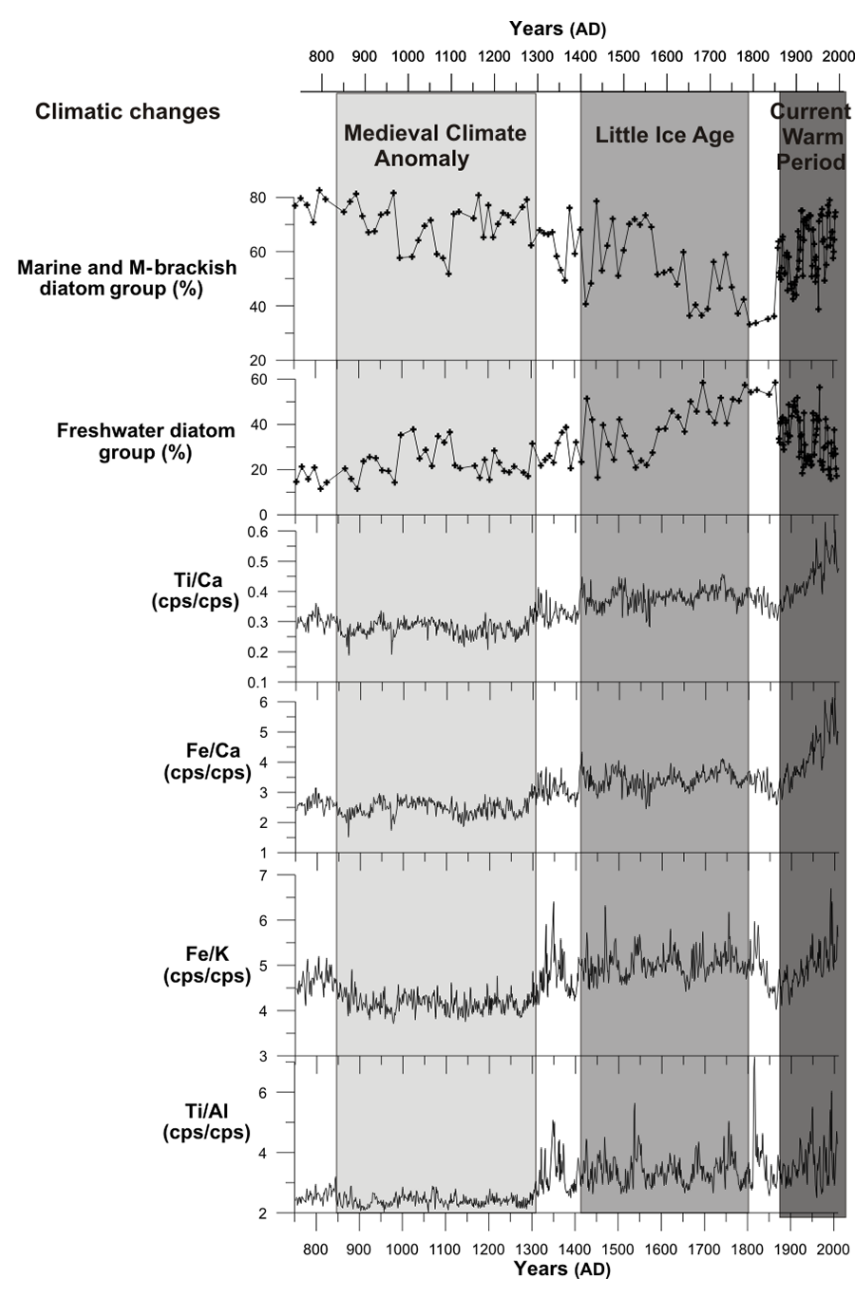

Figure 3. From bottom to top: centennial variation in $\mathrm{Ti} / \mathrm{Al}, \mathrm{Fe} / \mathrm{K}, \mathrm{Fe} / \mathrm{Ca}, \mathrm{Ti} / \mathrm{Ca}$ ratios, and the freshwater and marine/marine-brackish salinity-indicative diatom groups from the sediment core GeoB 13813-4 during the last $1200 \mathrm{yr}$ BP (7502000 cal yr AD). The major climatic changes during this period of time were the Medieval Climatic Anomaly and the Little Ice Age.

\subsubsection{Salinity-indicative diatom groups}

Regarding the salinity-indicative diatom groups as shown in Perez et al. (2016), the profile of group F seems to generally run parallel to those of the four element ratios with lower percentages around $20 \%$ during the MCA times, and higher up to $60 \%$, rising and more variable values during the LIA pe-

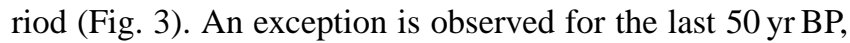
where the percentages declined rapidly towards the former values counted for the MCA time interval. In contrast, the M-B group ranged from 30 to $80 \%$, generally describing the expected opposite trend compared to the F group (Fig. 3). Over the last $100 \mathrm{yr}$ BP (AD 1900 up to the present), an increasing rapid trend coincides with the highest values shown for the element ratios (Fig. 3).

\section{Interpretation and discussion}

\subsection{Age-depth model and sedimentation rates}

The RdlP mud depocenter shows an exceptionally high sedimentation rate $\left(0.8 \mathrm{~cm} \mathrm{yr}^{-1}\right.$ on average; Perez et al., 2016) compared with other records from the southern Brazilian continental shelf (Mahiques et al., 2009; Chiessi et al., 2014). This high sedimentation rate is consequence of the enormous amount of sediment transported by the Paraná and Uruguay rivers into the RdlP watershed and further onto the Uruguayan shelf (Lantzsch et al., 2014). In addition, an amplification of the sedimentation rate could be a consequence of the fact that the RdlP paleovalley depression offers protection against strong hydrodynamic conditions on the shelf, favoring the deposition of sediments (Lantzsch et al., 2014; Hanebuth et al., 2016). The beginning of sedimentation is possibly associated with the establishment of humidity conditions in the late Holocene, which have resulted in an increasing RdlP discharge, as well as a significant sedimentation of terrigenous material over the RdlP paleovalley (Urien et al., 1980; Iriondo, 1999; Mahiques et al., 2009; Lantzsch et al., 2014; Perez et al., 2016).

\subsection{Paleoenvironmental proxy records}

The proxy data used in this study are correlated positively with each other (excluding the last century) and reveal the direct influence of the RdlP as a source of terrigenous sediments within the inner Uruguayan continental shelf.

The element ratios $\mathrm{Ti} / \mathrm{Ca}$ and $\mathrm{Fe} / \mathrm{Ca}$ indicate, like other geochemical and biological proxies, a mixed fluvio-marine signal on the inner Uruguayan continental shelf, spanning over the last 1200 years (Perez et al., 2016). Ti and Fe are supplied from the RdlP watershed (Depetris et al., 2003), while $\mathrm{Ca}$ is an element associated with calcareous organisms such as small mollusks, forams and coccolithophorids in the ocean, and therefore it is related to the marine-biogenic productivity of the continental shelf (Depetris and Pasquini, 2007; Govin et al., 2012; Razik et al., 2013). Thus the variability in these element ratios indicates different degrees of continental influence in the study area during the late Holocene.

The results of the proxies integral analysis have been linked to general climatic changes that have occurred on a regional to global scale (Fig. 3), and they allow us to infer three major time intervals, i.e., the MCA, the LIA and the current warm period (Mann et al., 2009), all of which were characterized by changing continental versus marine influences in the study area.

The oldest recorded period, from AD 800 to 1300, is closely associated with the MCA (reported as a positive temperature anomaly in the Northern Hemisphere; Bradley et al., 2008; Mann et al., 2009). During this period, a strong and steady influence of marine conditions governed the in- 
Table 2. High-resolution $\delta^{18} \mathrm{O}$ records related to SAMS changes for the MCA and the LIA.

\begin{tabular}{|c|c|c|c|c|c|}
\hline Reference & Site & Proxy & MCA & LIA & Inferred climatic context \\
\hline Bird et al. (2011b) & $\begin{array}{l}\text { Pumacocha Lake, } \\
\text { Peru (Andes). }\end{array}$ & $\begin{array}{l}\text { Lake sediment } \\
\left.\text { (calcite } \delta^{18} \mathrm{O}\right) \text {. }\end{array}$ & $\begin{array}{l}\text { More positive } \\
\delta^{18} \mathrm{O} \text { values }\end{array}$ & $\begin{array}{l}\text { More negative } \\
\delta^{18} \mathrm{O} \text { values }\end{array}$ & $\begin{array}{l}\text { SAMS sensitive to ITCZ } \\
\text { and } \mathrm{NH} \text { temperatures. }\end{array}$ \\
\hline Vuille et al. (2012) & $\begin{array}{l}\text { Review: tropical } \\
\text { Andes and SE Brazil. }\end{array}$ & $\begin{array}{l}\delta^{18} \mathrm{O} \text { (speleothem, } \\
\text { ice and sediment cores). }\end{array}$ & $\begin{array}{l}\text { (indicative of } \\
\text { the dry season) }\end{array}$ & $\begin{array}{l}\text { (indicative of } \\
\text { the wet season) }\end{array}$ & $\begin{array}{l}\text { SAMS modulated by changes } \\
\text { in the North Atlantic. }\end{array}$ \\
\hline Apaéstegui et al. (2014) & $\begin{array}{l}\text { Palestina Cave, } \\
\text { Peru (Andes). }\end{array}$ & $\begin{array}{l}\text { Speleothem } \\
\delta^{18} \mathrm{O}\end{array}$ & $\begin{array}{l}\text { related to a weakening } \\
\text { of SAMS activity. }\end{array}$ & $\begin{array}{l}\text { related to a strengthening } \\
\text { of SAMS activity. }\end{array}$ & SAMS modulated by AMO. \\
\hline
\end{tabular}

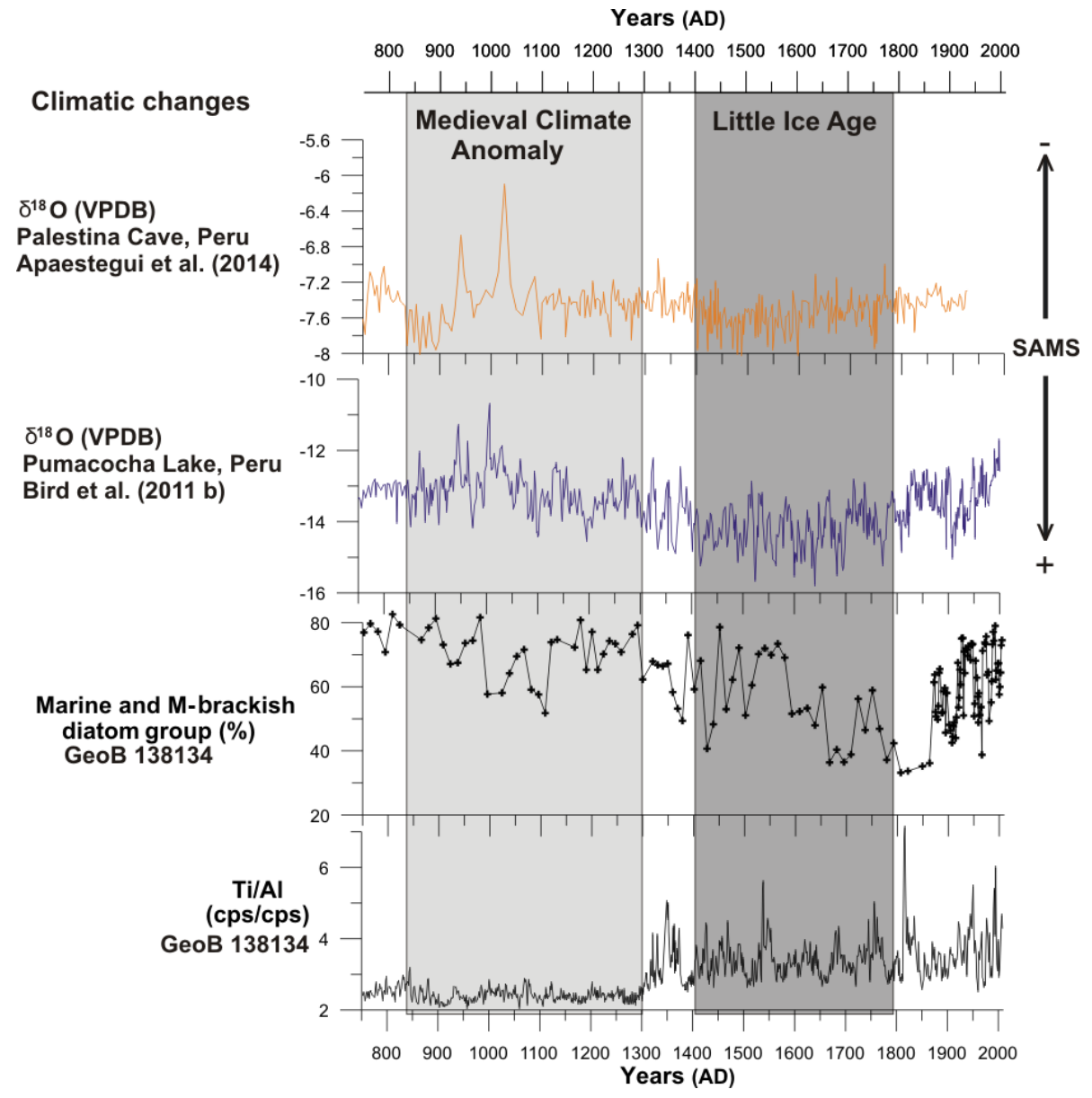

Figure 4. From top to bottom: Palestina Cave and Pumacocha Lake $\delta^{18} \mathrm{O}$ records of SAMS intensity (Apaéstegui et al., 2014; Bird et al., 2011b), the marine/marine-brackish salinity-indicative diatom group and Ti / Al ratios from the sediment core GeoB 13813-4 during the last $1200 \mathrm{yr}$ BP (750-2000 cal yr AD). Note that the lowest $\delta^{18} \mathrm{O}$ values (Apaéstegui et al., 2014; Bird et al., 2011b) are associated with higher rainfall and stronger SAMS activity, which correspond to higher Ti / Al and lower relative abundance of marine diatoms.

ner Uruguayan continental shelf (inferred by low values of $\mathrm{Ti} / \mathrm{Ca}$ and $\mathrm{Fe} / \mathrm{Ca}$, and a dominance of the $\mathrm{M}-\mathrm{B}$ diatom salinity group), probably as a result of a weakened RdlP water and terrigenous sediment discharge. This situation led to a major and more constant sedimentation of marine particulate carbon during the MCA (Perez et al., 2016). In addition, the low $\mathrm{Fe} / \mathrm{K}$ values registered during the MCA would suggest conditions of reduced RdlP river discharge and dry conditions over the drainage basin (Vuille et al., 2012). Climatically drier conditions appear to decrease chemical weather- ing in the Fe-rich RdlP drainage basin, thus depleting the $\mathrm{Fe}$ content in the offshore depocenters in relation to $\mathrm{K}$, which is associated with drier conditions (Depetris et al., 2003; Depetris and Pasquini et al., 2007).

Our findings, combined with those reported in other studies, suggest a weakened SAMS during the MCA (Fig. 4; Bird et al., 2011a, b; Vuille et al., 2012; Apaéstegui et al., 2014; Salvatecci et al., 2014). Though the continental SAMS exhibits spatial-temporal characteristics that differ from the ITCZ, the latitudinal position of the ITCZ is closely related 
to changes in the SAMS intensity, and both climatic elements also respond to temperature anomalies in the Northern Hemisphere, especially in the North Atlantic (Table 2, Stríkis et al., 2011; Bird et al., 2011b; Vuille et al., 2012; Apaéstegui et al., 2014). In this sense, positive/negative Northern Hemisphere temperature anomalies are linked to the north/south directional migration of the ITCZ thus diminishing/increasing SAMS activity (Broccoli et al., 2006; Bird et al., 2011b; Stríkis et al., 2011; Vuille et al., 2012). Hence, the positive temperature anomalies in the Northern Hemisphere during the MCA (Mann et al., 2009; probably associated with a positive phase of the AMO) led to reduced SAMS and SACZ intensity, in addition to a northward displacement of the ITCZ (Fig. 4, Chiessi et al., 2009; Bird et al., 2011b; Stríkis et al., 2011; Vuille et al., 2012; Apaéstegui et al., 2014). Such atmospheric conditions during the MCA led to a significant decrease in rainfall over the RdlP watershed (mainly in the catchment area of its main tributary, the Paraná River; Robertson and Mechoso, 2000). As a consequence of this, we inferred a reduction in both freshwater and sediment input, in conjunction with an increase in salinity (Perez et al., 2016) on the Uruguayan continental shelf. The decrease in SACZ activity during the MCA could also help explain the more humid conditions inferred for Uruguay during this episode (del Puerto et al., 2013). This is associated with an increase in precipitation over the Uruguay River drainage basins due to a reduced SACZ intensity as discussed below (Robertson and Mechoso, 2000).

The following period, from AD 1300 to 1850 , coincided with the LIA as reported for the Northern Hemisphere (Bradley et al., 2003; Mann et al., 2009). This period is characterized by higher values of $\mathrm{Ti} / \mathrm{Al}, \mathrm{Fe} / \mathrm{K}, \mathrm{Ti} / \mathrm{Ca}$ and $\mathrm{Fe} / \mathrm{Ca}$ than those recorded during the preceding period (Fig. 3). Therefore, we recorded a higher content of terrigenous material rich in Ti and Fe from the RdlP watershed (Depetris et al., 2003; Depetris and Pasquini, 2007), which is associated with a higher river discharge during the LIA. Furthermore, a dominance of $\mathrm{F}$ diatoms was detected (Fig. 3). The F diatom group was mainly dominated by Aulacoseira spp., especially A. granulata (Perez et al., 2016), which is the most common diatom genus from the Paraná River and the inner RdlP (Gomez and Bauer, 2000; Licursi et al., 2006; Devercelli et al., 2014). Moreover, Massaferro et al. (2014) observed that the $\mathrm{F}$ diatom group recorded in the uppermost $55 \mathrm{~cm}$ of the sediment core GeoB 13813-4 was associated with the positive anomalies of the Paraná River discharges. Thus, all the proxies indicate wetter conditions over the RdlP drainage basin and, consequently, a major freshwater supply from the RdlP to the inner Uruguayan shelf during the LIA. Accordingly, we observed the highest rates of terrigenous deposition during this episode.

The LIA, characterized by cold conditions over the Northern Hemisphere, was thus related to a strengthening of SAMS and SACZ (Fig. 4; Bird et al., 2011b; Vuille et al., 2012; Apaéstegui et al., 2014). This leads to a reduction in rainfall rates over northern South America, Central America and Mexico (Haug et al., 2001; Vazques-Castro et al., 2008) as well as elevated rainfall rates in the Andes (Sifeddine et al., 2008; Bird et al., 2011a, b; Vuille et al., 2012; Apaéstegui et al., 2014; Salvatecci et al., 2014) and over SESA (southeastern South America) (Meyer and Wagner, 2009; Vuille et al., 2012). The intensification and northward displacement of the Southern Westerlies during the LIA was also registered (Moy et al., 2009; Koffman et al., 2014). This, in conjunction with a higher river discharge, would have also caused an anomalous northward shift of the RdIP river plume. Such atmospheric conditions during the LIA have led to a significant increase in rainfall over the RdlP watershed. Therefore, the outcome was a higher influence of the RdlP river plume within the inner Uruguayan continental shelf as recorded in this study.

The succession of maximum and minimum peaks in the element ratios from $\mathrm{AD} 1300$ to present (every 50 to 100 years) suggests an influence of the AMO on RdlP river discharge related to changes in SAMS and SACZ intensity (Chiessi et al., 2009; Stríkis et al., 2011). The AMO significantly affects the SAMS at multidecadal timescales, leading to a reduced SAMS intensity when the AMO is in its positive phase, and the ITCZ retreats northward, leading to a decrease in RdIP river discharge (Table 2, Chiessi et al., 2009; Strikis et al., 2011; Bird et al., 2011b; Apaéstegui et al., 2014).

An increase in SACZ intensity during the LIA and its decrease during the MCA, inferred in this study, explain the contrasting spatial/temporal climatic conditions recorded in the two regions in the RdIP drainage basin (SE Brazil: Vuille et al., 2012; Uruguay: del Puerto et al., 2013). SACZ intensity is associated with increased river runoff in the northern region of the RdlP catchment area (Paraná River) and a decreased runoff in the southern area (Uruguay River; Robertson and Mechoso, 2000). The north/south river runoff contrast, in response to an intensified/weakened SACZ, appear to transport less/more moisture over the Uruguay River basin, thus leading to an increase/decrease in precipitation during the MCA/LIA over Uruguay (del Puerto et al., 2013).

\section{Conclusions}

The observed changes in the presented proxy records indicate variations in both the continental runoff and the marine influence related to regional climatic variability. Therefore, we put forward the suggestion that global atmospheric changes (related to changes in SAMS and SACZ intensity) have made an impact on the hydrodynamics and, consequently, on the local sedimentation regime and the inner Uruguayan continental shelf over the past 1200 cal yr BP (AD 750-2000).

During the MCA (AD 800-1300) a reduction in SAMS and SACZ activities would have caused a decrease in the rainfall rate over the RdlP drainage basin, resulting in more estuarine-marine conditions predominating over a freshwa- 
ter plume signal. During the LIA (AD 1400-1800), in contrast, a strengthening in SAMS and SACZ activities led to increased precipitation over the RdlP drainage basin, reflected by stronger terrigenous influences in terms of freshwater supply on the inner Uruguayan shelf. Furthermore, a possible multidecadal oscillation probably associated with AMO since AD 1300 reflects the variability in both the SAMS and SACZ systems.

\section{The Supplement related to this article is available online at doi:10.5194/cp-12-623-2016-supplement.}

Acknowledgements. We would like to express special thanks to Ines Sunesen, Eugenia Sar, Michel Mahiques and Carina Lange for their fruitful discussions. We would also like to thank Vivienne Pettman for her very valuable suggestions for improving the English and also Thorsten Kiefer and the three anonymous reviewers for their critical comments and suggestions, which undoubtedly improved the manuscript content. We acknowledge PEDECIBA (Programa para el Desarrollo de las Ciencias Básicas) Geociencias, ANII (Agencia Nacional de Investigación e Innovación), DAAD (German Academic Exchange Service), and RLB (Red Latinoamericana de Botanica) for their financial support. The authors would also like to thank PAGES for their partially financial support of this publication. This article is an outcome of the MARUM SD2 project as part of the DFG 543 Research Center/Excellence Cluster "The Ocean in the Earth System" at the University of Bremen.

Edited by: T. Kiefer

\section{References}

Acha, E., Mianzan, H., Iribarne, O., Gagliardini, D., Lasta, C., and Daleo, P.: The role of the Río de la Plata bottom salinity front in accumulating debris, Mar. Poll. Bull., 46, 197-202, 2003.

Almeida, R. A. F., Nobre, P., Haarsma, R. J., and Campos, E. J. D.: Negative ocean-atmosphere feedback in the South Atlantic Convergence Zone, Geophys. Res. Lett., 34, L18809, doi:10.1029/2007GL030401, 2007.

Apaéstegui, J., Cruz, F. W., Sifeddine, A., Vuille, M., Espinoza, J. C., Guyot, J. L., Khodri, M., Strikis, N., Santos, R. V., Cheng, H., Edwards, L., Carvalho, E., and Santini, W.: Hydroclimate variability of the northwestern Amazon Basin near the Andean foothills of Peru related to the South American Monsoon System during the last 1600 years, Clim. Past, 10, 1967-1981, doi:10.5194/cp-10-1967-2014, 2014.

Barreiro, M.: Influence of ENSO and the South Atlantic Ocean on climate predictability over Southeastern South America, Clim. Dynam., 35, 1493-1508, doi:10.1007/S00382-009-06669, 2010.

Bender, V. B., Hanebuth, T. J. J., and Chiessi, C. M.: Holocene shifts of the subtropical shelf front off Southeastern South America controlled by high and low latitude atmospheric forcings, Paleoceanography, 28, 1-10, doi::10.1002/palo.20044, 2013.
Bird, B. W., Abbott, M. B., Rodbell, D. T., and Vuille, M.: Holocene tropical South American hydroclimate revealed from a decadally resolved lake sediment $\delta 180$ record, Earth Planet. Sc. Lett., 310, 192-202, 2011a.

Bird, B. W., Abbott, M. B., Vuille, M., Rodbell, D. T., Stansella, N. D., and Rosenmeiera, M. F.: 2300-year-long annually resolved record of the South American summer monsoon from the Peruvian Andes, P. Natl. Acad. Sci. USA, 108, 8583-8588, 2011 b.

Bisbal, G. A.: The southeast South American shelf large marine ecosystem: Evolution and components, Mar. Policy, 19, 21-38, 1995.

Blaauw, M. and Christen, J. A.: Flexible paleoclimate age-depth models using an autoregressive gamma process, Bay. Anal., 6, 457-474, 2011.

Bradley, R. S., Hughes, M. K., and Diaz, H. F.: Climate in Medieval Time, Science, 302, 404-405, 2008.

Broccoli, A. J., Dahl, K. A, and Stouffer, R. J.: Response of the ITCZ to Northern Hemisphere cooling, Geophys. Res. Lett., 33, L01702, doi:10.1029/2005GL024546, 2006.

Burone, L., Centurión, V., Cibils, L., Franco-Fraguas, P., GarcíaRodríguez, F., García, G., and Pérez, L.: Sedimentología y Paleoceanografía, in: Programa oceanográfico de caracterización del margen continental uruguayo-ZEE, edited by: Burone, L., Montevideo, Uruguay, 240-295, 2012.

Burone, L., Ortega, L., Franco-Fraguas, P., Mahiques, M., GarcíaRodríguez, F., Venturini, N., Marin, Y., Brugnoli, E., Nagai, R., Muniz, P., Bicego, M., Figueira, R., and Salaroli, A.: A multiproxy study between the Río de la Plata and the adjacent Southweastern Atlantic inner shelf to asses the sediment footprint of river vs. marine influence, Cont. Shelf Res., 55, 141-154, 2013.

Camilloni, I.: Variabilidad y tendencias hidrológicas en la cuenca del Plata, in: El cambio climático en el Río de la Plata, edited by: Barros, V., Menendez, A., and Nagy, G., CIMA, Buenos Aires, 20-31, 2005.

Carvalho, L. M. V., Jones, C., and Liebmann, B.: The South Atlantic Convergence Zone: Intensity, Form, Persistence, and Relationships with Intraseasonal to Interannual Activity and Extreme Rainfall, J. Climate, 17, 88-108, 2004.

Chiessi, C. M., Mulitza, S., Patzold, J., Wefer, G., and Marengo, J. A.: Possible impact of the Atlantic Multidecadal Oscillation on the South American summer monsoon, Geophys. Res. Lett., 36, L21707, doi:10.1029/2009GL039914, 2009.

Chiessi, C. M., Mulitza, S. G., Jeroen, S. J. B., Campos, M. C., and Gurgel, M. H. C.: Variability of the Brazil Current during the late Holocene, Palaeogeogr. Palaeocl., 415, 28-36, doi:10.1016/j.palaeo.2013.12.005, 2014.

Cioccale, M.: Climatic conditions in the central region of Argentina in the last 1000 years, Quaternary Int., 62, 35-47, 1999.

Ciotti, A. M., Odebrecht, C., Fillmann, G., and Moller, O. O.: Freshwater outflow and Subtropical Convergence influence on phytoplankton biomass on the southern Brazilian continental shelf, Cont. Shelf. Res., 15, 1737-1756, 1995.

del Puerto, L., García-Rodríguez, F., Bracco, R., Castiñeira, C., Blasi, A., Inda, H., Mazzeo, N., and Rodríguez, A.: Evolución climática holocénica para el sudeste de Uruguay, Analisis multiproxy en testigos de lagunas costeras, in: El Holoceno en la zona costera de Uruguay, edited by: García-Rodríguez, F., Universidad de la Republica (UdelaR), 117-154, 2011. 
del Puerto, L., Bracco, R., Inda, H., Gutierrez, O., Panario, D., and García-Rodríguez, F.: Assessing links between late Holocene climate change and paleolimnological development of Peña Lagoon using opal phytoliths, physical, and geochemical proxies, Quaternary Int., 287, 89-100, doi:10.1016/j.quaint.2011.11.026, 2013.

Depetris, P. J. and Kempe, S.: The impact of the E1 Niño 1982 event on the Paraná River, its discharge and carbon transport, Palaeogeogr. Palaeocl., 89, 239-244, 1990.

Depetris, P. J. and Pasquini, A. I.: Discharge trends and flow dynamics of southern southamerican rivers draining the southern Atlantic seabord: an overview, J. Hydrol., 333, 385-399, doi:10.1016/j.hydrol.2006.09005, 2007.

Depetris, P. J., Probst, J.-L., Pasquini, A. I., and Gaiero, D. M.: The geochemical characteristics of the Paraná River suspended sediment load: an initial assessment, Hydrol. Process, 17, 12671277, doi:10.1002/hyp.1283, 2003.

Devercelli, M., Zalocar de Domitrovic, Y., Forastier, M. E., and Meichtry de Zaburlín N.: Phytoplankton of the Paraná River Basin, Advanc. Limnol., 65, 39-65, doi:10.1127/1612166X/2014/0065-0033, 2014.

Francus, P., Lamb, H., Nakawaga, T., Marshall, M., and Brown, E.: The potential of high resolution X-ray fluorescense core scanning: Aplications in paleolimnology, PAGES news, 17, 9, 93-95, 2009.

Frenguelli, J.: Diatomeas del Río de la Plata, Revista Museo Nacional La Plata, III, 213-334, 1941.

Frenguelli, J.: Diatomeas del Platense, Revista Museo Nacional La Plata, III, 77-221, 1945.

FREPLATA: Análisis Diagnóstico Transfronterizo del Río de la Plata y su Frente Marítimo, Documento Técnico, Proyecto "Protección Ambiental del Río de la Plata y su Frente Marítimo: Prevención y Control de la Contaminación y Restauración de Hábitats", Proyecto PNUD/GEF/RLA/99/G31, 106, 2004.

Garcia, S. and Kayano, M.: Some evidence on the relationship between the South American monsoon and the Atlantic ITCZ, Theor. Appl. Climatol., 99, 29-38, 2010.

García-Rodríguez, F., Brugnoli, E., Muniz, P., Venturini, N., Burone, L., Hutton, M., Rodríguez, M., Pita, A., Kandratavicius, N., Perez, L., and Verocai, J.: Warm-phase ENSO events modulate the continental freshwater input and the trophic state of sediments in a large South American estuary, Mar. Freshwater Res., $65,1-11,2014$.

Garreaud, R. D., Vuille, M., Compagnucci, R., and Marengo, J.: Present-day South American climate, Palaeogeogr. Palaeocl., 281, 180-195, 2009.

Giberto, D. A., Bremec, C. S., Acha, E. M., and Mianzan, H.: Largescale spatial patterns of benthic assemblages in the SW Atlantic: the Río de la Plata, Estuar. Coast. Shelf S., 61, 1-13, 2004.

Goldberg, E. D. and Arrhenius, G. O. S.: Geochemistry of pacific pelagic sediments, Geochim. Cosmochim. Ac., 13, 153$212,1958$.

Gómez, N. and Bauer, D. E.: Diversidad fitoplanctónica en la franja costera Sur del Río de la Plata, Biol. Acuát., 19, 7-26, 2000.

González-Mora, B. and Sierro, F. J.: Caracterización geoquímica de las capas ricas en materia orgánica registradas durante el estadio isotópico marino 7 en el Mar de Alborán (Mediterráneo occidental), GEOGACETA, 43, 111-114, 2007.
Govin, A., Holzwarth, U., Heslop, D., Ford Keeling, L., Zabel, M., Mulitza, S., Collins, J. A., and Chiessi, C. M.: Distribution of major elements in Atlantic surface sediments $\left(36^{\circ} \mathrm{N}-49^{\circ} \mathrm{S}\right)$ : Imprint of terrigenous input and continental weathering, Geochem. Geophy. Geosy., 13, 1525-2027, 2012.

Guerrero, R., Acha, E., Framiñan, M., and Lasta, C.: Physical oceanography of the Rio de la Plata Estuary, Argentina, Cont. Shelf. Res., 17, 727-742, 1997.

Haberzettl, T., Fey, M., Lucke, A., Maidana, N., Mayr, C., Ohlendorf1, C., Schabitz, F., Schleser, G. H., Wille, M., and Zolitschka, B.: Climatically induced lake level changes during the last two millennia as reflected in sediments of Laguna Potrok Aike, southern Patagonia (Santa Cruz, Argentina), J. Paleolimnol., 33, 283 302, 2005.

Hanebuth, T. J. J., Lantzsch, H., García-Rodríguez, F., and Perez, L.: Currents controlling sedimentation: paleo-hydrodynamic variability inferred from the continental-shelf system off SE South America (Uruguay), in: Ciencias Marino Costeras en el Umbral del Siglo XXI: Desafíos en Latinoamérica y el Caribe (XV COLACMAR), edited by: Muniz, P., Conde, D., Venturini, N., and Brugnoli, E., in press, 2016.

Hasle, G. R. and Syvertsen, E. E.: Marine diatoms, in: Identifying marine phytoplankton, edited by: Tomas, C. R., Academic Press, San Diego, California, 5-385, 1996.

Hassan, G.: Paleoecological significance of diatoms in argentinean estuaries, Consejo Nacional de Investigaciones Científicas y Técnicas (CONICET), Argentina, 2010.

Haug, G. H., Hughen, K. A., Sigman, D. M., Peterson, L. C., and Rohl, U.: Southward Migration of the Intertropical Convergence Zone through the Holocene, Science, 293, 1304-1307, doi:10.1126/science.1059725, 2001.

Iriondo, M.: Climatic changes in the South American plains: Records of a continent-scale oscillation, Quaternary Int., 57-58, 93-112, 1999.

Jansen, J. H. F., Van der Gaast, S. J., Koster, B., and Vaars, A. J.: CORTEX, a shipboard XRF-scanner for element analyses in split sediment cores, Mar. Geol., 151, 143-153, 1998.

Koffman, B. G., Kreutz, K. J., Breton, D. J., Kane, E. J., Winski, D. A., Birkel, S. D., Kurbatov, A. V., and Handley, M. J.: Centennial-scale variability of the Southern Hemisphere westerly wind belt in the eastern Pacific over the past two millennia, Clim. Past, 10, 1125-1144, doi:10.5194/cp-10-1125-2014, 2014.

Krastel, S., Wefer, G., Hanebuth, T. J. J., Antobreh, A. A., Freudenthal, T., Preu, B., Schwenk, T., Strasser, M., Violante, R., and Winkelmann, D.: Sediment dynamics and geohazards off Uruguay and the de la Plata River region (northern Argentina and Uruguay), Geo-Mar. Lett., 31, 271-283, doi:10.1007/s00367011-0232-4, 2011.

Krastel, S., Wefer, G., and cruise participants: Sediment transport off Uruguay and Argentina: From the shelf to the deep sea, 19 May 2009-06 July 2009, Montevideo (Uruguay) - Montevideo (Uruguay), Report and preliminary results of RV METEOR Cruise M78/3, Berichte, Fachbereich Geowissenschaften, Universität Bremen, 285, 2012.

Lantzsch, H., Hanebuth, T. J. J., Chiessi, C. M., Schwenk, T., and Violante, R.: A high-supply sedimentary system controlled by strong hydrodynamic conditions (the continental margin off the Plata Estuary during the late Quaternary, Quaternary Res., 81, 339-354, 2014. 
Licursi, M., Sierra, M. V., and Gómez, N.: Diatom assemblages from a turbid coastal plain estuary: Río de la Plata (South America), J. Mar. Syst., 62, 33-45, 2006.

Löwemark, C., Chen, H., Yang, T.-N., Kylander, M., Yu, E.-F., Hsu, Y.-W., Lee, T.-Q., Song, S.-R., and Jarvis, S.: Normalizing XRF scanner data: A cautionary note on the interpretation of highresolution records from organic-rich lakes, J. Assia Earth Sci., 40, 1250-1256, 2011.

Mahiques, M. M., Wainer, I. K. C., Burone, L., Nagai, R., Sousa, S. H. M., Lopes Figueira, R. C., da Silveira, I. C. A., Bicego, M. C., Alves, D. P. V., and Hammer, O.: A high-resolution Holocene record on the Southern Brazilian shelf: Paleoenvironmental implications, Quaternary Int., 206, 52-61, 2009.

Mahowald, N. M., Muhs, D. R., Levis, S., Rasch, P. J., Yoshioka, M., Zender, C. S., and Luo, C.: Change in atmospheric mineral aerosols in response to climate: Last glacial period, preindustrial, modern, and doubled carbon dioxide climates, J. Geophys. Res., 111, D10202, doi:10.1029/2005JD006653, 2006.

Mann, M. E., Zhang, Z., Rutherford, S., Bradley, R. S., Hughes, M., Shindell, D., Ammann, D., Faluvegi, G., and Ni, F.: Global Signatures and Dynamical Origins of the Little Ice Age and Medieval Climate Anomaly, Science, 326, 1256-1259, 2009.

Martins, V., Dubert, J., Jouanneau, J.-M., Weber, O., Ferreira da Silva, E., Patinha, C., Alverinho Dias, J. M., and Rocha, F.: A multyproxy approach of the Holocene evolution of shelf-slope circulation on the NW Iberian continental shelf, Mar. Geol., 239, 1-18, 2007.

Martins, L. R., Martins, I. R., and Urien, C. M.: Aspectos sedimentares da plataforma continental na área de influencia de Rio de La Plata, Gravel, 1, 68-80, 2003.

Martins, L. R. and Urien, C. R.: Areias da plataforma e a erosao costeira, Gravel, 2, 4-24, 2004.

Masello, A. and Menafra, R.: Macrobenthic comunities of the Uruguayan coastal zona and adjacent areas, in: Río de la Plata una revisión ambiental, edited by: Wells, P. G. and Daborn, G. R., University of Dalhousie, 140-186, 1998.

Massaferro, J., Perez, L., de Porras, M. E., Pérez Becoña, L., Tonello, M., and Juggins, S.: Paleoecological data analysis with $\mathrm{R}$, course for Latin American researchers, Pages Magazine, Workshop reports, 22, 105-105, 2014.

Metzeltin, D. and García-Rodríguez, F. (Eds): Las Diatomeas Uruguayas, Facultad de Ciencias, Montevideo, Uruguay, 654 pp., 2003.

Metzeltin, D., Lange-Bertalot, H., and García-Rodríguez, F.: Diatoms of Uruguay - Taxonomy, Biogeography, Diversity, in: Iconographia Diatomologica (15), edited by: Lange-Bertalot, $\mathrm{H}$. and Gantner Verlag, A. R. G., Koenigstein, Germany, 736 pp., 2005.

Meyer, I. and Wagner, I.: The Little Ice Age in Southern South America: Proxy and model based evidence, in: Past climate variability in South America and surrounding regions, from the last glacial maximum to the Holocene, edited by: Vimeux, F., Sylvestre, F., and Khodri, M., Springer, 395-412, 2009.

Möller Jr., O. O., Piola, A. R., Freitas, A. C., and Campos, E.: The effects of river discharge and seasonal winds on the shelf off southeastern South America, Cont. Shelf Res., 28, 1603-1624, 2008.

Moy, C. M., Moreno, P. I., Dunbar, R. B., Kaplan, M. R., Francois, J.-P., Villalba, R., and Haberzettl, T.: Climate change in South- ern South America during the last two millennia, in: Past climate variability in South America and surrounding regions, edited by: Vimeux, F., Sylvestre, F., and Khodri, M., Developments in Paleoenvironmental Research (14), Springer, 353-393, 2009.

Müller-Melchers, P.: Diatomeas procedentes de algunas muestras de turba del Uruguay, Comunicaciones Botánicas del Museo de Historia Natural de Montevideo, 1, 1-25, 1945.

Müller-Melchers, P.: Sobre algunas diatomeas planctónicas de Atlántida (Uruguay), Physis, 20, 459-466, 1953.

Müller-Melchers, P.: Plankton diatoms of the Southern Atlantic of Argentina and Uruguay coast, Comunicaciones Botánicas del Museo de Historia Natural de Montevideo 3, 1-53, 1959.

Nagai, R. H., Ferreira, P. A. L., Mulkherjee, S., Martins, V. M., Figueira, R. C. L., Sousa, S. H. M., and Mahiques, M. M.: Hidrodinamic controls on the distribution of surface sediments from the southeast South American continental shelf between $23^{\circ} \mathrm{S}$ and $38^{\circ} \mathrm{S}$, Cont. Shelf. Res., 89, 51-60, doi:10.1016/j.csr.2013.09.016, 2014.

Nogués-Paegle, J., Mechoso, C. R., Fu, R., Berbery, E. H., Chao, W. C., Chen, T.-C., Cook, K., Diaz, A. F., Enfield, D., Ferreira, R., Grimm, A. M., Kousky, V., Liebmann, B., Marengo, J., Mo, K., Neelin, J. D., Paegle, J., Robertson, A. W., Seth, A., Vera, C. S., and Zhou, J.: Progress in Pan American CLIVAR research: Understanding the South American monsoon, Meteorologica, 27, 3-32, 2002.

Perez, L., García-Rodríguez, F., and Hanebuth, T.: Paleosalinity changes in the Río de la Plata estuary and on the adjacent Uruguayan continental shelf over the past $1200 \mathrm{cal} \mathrm{ka} \mathrm{BP:} \mathrm{an}$ approach using diatoms as proxy, in: Applications of paleoenvironmental techniques in estuarine studies, Developments in $\mathrm{Pa}-$ leoenvironmental Research (DPER), edited by: Weckström, K., Saunders, P., and Skilbeck, G., Springer, 2016.

Piola, A. R., Campos, E. J. D., Möller Jr., O. O., Charo, M., and Martinez, C. M.: Subtropical shelf front off eastern South America, J. Geophys. Res., 105, 6566-6578, 2000.

Piola, A. R., Moller, O. O., Guerrero, R. A., and Campos, E. J. D.: Variability of the subtropical shelf front off eastern South America: Winter 2003 and summer 2004, Cont. Shelf Res., 28, 16391648, doi:10.1016/j.csr.2008.03.013, 2008.

Piovano, E. L., Ariztegui, D., Cordoba, F., Cioccale, J., and Sylvestre, F.: Hydrological variability in South America below the tropic of Capricorn (Pampas and Patagonia, Argentina) during the Last 13.0 Ka, in: Past climate variability in South America and surrounding regions, from the last glacial maximum to the Holocene, edited by: Vimeux, F., Sylvestre, F., and Khodri, M., Springer, 323-352, 2009.

Razik, S., Chiessi, C. M., Romero, O. E., and von Dobeneck, T.: Interaction of the South American Monsoon System and the Southern Westerly Wind Belt during the last 14 kyr, Palaeogeogr. Palaeocl., 374, 28-40, 2013.

Reimer, P. J., Bard, E., Bayliss, A., Beck, J. W., Blackwell, P. G., Bronk Ramsey, C., Buck, C. E., Edwards, R. L., Friedrich, M., Grootes, P. M., Guilderson, T. P., Haflidason, H., Hajdas, I., Hatté, C., Heaton, T. J., Hoffmann, D. L., Hogg, A. G., Hughen, K. A., Kaiser, K. F., Kromer, B., Manning, S. W., Niu, M., Reimer, R. W., Richards, D. A., Scott, M. E., Southon, J. R., Turney, C. S. M., and van der Plicht, J.: IntCal13 and Marine13 radiocarbon age calibration curves $0-50000$ yr cal BP, Radiocarbon, 55, 1869-1887, 2013. 
Robertson, A. W. and Mechoso, C. R.: Interannual and interdecadal variability of the South Atlantic Convergence Zone, Mon. Weather Rev., 128, 2947-2957, 2000.

Romero, O. E., Lange, C. B., Fischer, G., Treppke, U. F., and Wefer, G.: Variability in export production documented by downward fluxes and species composition of marine panctonic diatoms: Observations from the tropical and ecuatorial Atlantic, in: Use of proxies in paleoceanography: Examples from the South Atlantic, edited by: Fischer, G. and Wefer, G., Universität Bremen, Springer, Germany, 365-392, 1999.

Salazar, A., Lizano, O. G., and Alfaro, E. J.: Composición de sedimentos en las zonas costeras de Costa Rica utilizando Fluorescencia de Rayos-X (FRX), Rev. Biol. Trop., 52, 0034-7744, 2004.

Salvatteci, R., Gutiérrez, D., Field, D., Sifeddine, A., Ortlieb, L., Bouloubassi, I., Boussafir, M., Boucher, H., and Cetin, F.: The response of the Peruvian Upwelling Ecosystem to centennial-scale global change during the last two millennia, Clim. Past, 10, 715731, doi:10.5194/cp-10-715-2014, 2014.

Sar, E. A., Sunesen, I., and Lavigne, A. S.: Cymatotheca, Tryblioptychus, Skeletonema and Cyclotella (Thalassiosirales) from Argentinian coastal waters. Description of Cyclotella cubiculata sp. nov., Vie milieu, 60, 135-156, 2010.

Siffedine, A., Gutiérrez, D., Ortlieb, L., Boucher, H., Velazco, F., Field, D., Vargas, G., Boussafire, M., Salvatteci, R., Ferreira, V., García, M., Valdés, J., Caquineau, S., Mandeng Yogo, M., Cetin, F., Solis, J., Soler, P., and Baumgartner, T.: Laminated sediments from the central Peruvian continental slope: A 500 year record of upwelling system productivity, terrestrial runoff and redox conditions, Prog. Oceanogr., 79, 2-4, 190-197, 2008.

Strikis, N. M., Cruz Jr., F. W., Cheng, H., Karmann, I., Edwards, R. L., Vuille, M., Wang, X., de Paula, M. S., Novello, V. F., and Auler, A. S.: Abrupt variations in South American monsoon rainfall during the Holocene based on a speleothem record from central-eastern Brazil, Geology, 39, 1075-1078, 2011.
Urien, C. M. and Ewing, M.: Recent sediments and environment of southern Brazil, Uruguay, Buenos Aires, and Rio Negro continental shelf, in: The Geology of Continental Margins, edited by: Burk, C. A. and Drake, C. L., Springer, New York, 157-177, 1974.

Urien, C. M., Martins, L. R., and Martins, I. R.: Evolução geológica do Quaternário do litoral atlântico uruguaio, plataforma continental e regiões vizinhas, Notas Técnicas, CECO/URFGS, 3, 7-43, 1980.

Vázquez-Castro, G., Ortega-Guerrero, B., Rodríguez, A., Caballero, M., and Lozano-García, S.: Mineralogía magnética como indicador de sequía en los sedimentos lacustres de los últimos $c a$. 2,600 años de Santa María del Oro, occidente de México, Rev. Mex. Cienc. Geol., 25, 21-38, 2008.

Vuille, M., Burns, S. J., Taylor, B. L., Cruz, F. W., Bird, B. W., Abbott, M. B., Kanner, L. C., Cheng, H., and Novello, V. F.: A review of the South American monsoon history as recorded in stable isotopic proxies over the past two millennia, Clim. Past, 8, 1309-1321, doi:10.5194/cp-8-1309-2012, 2012.

Weltje, G. J. and Tjallingii, R.: Calibration of XRF core scanners for quantitative geochemical logging of sediment cores: Theory and application, Earth Planet. Sci Lett., 274, 423-438, doi:10.1016/j.epsl.2008.07.054, 2008.

Witkowski, A., Lange-Bertalot, H., and Metzeltin, D.: Diatom flora of marine coasts 1 , in: Iconographia Diatomologica, edited by: Lange-Bertalot, H. and Gantner Verlag A. R. G., 7, 925, 2000.

Yarincik, K., Murray, M., R. W., and Peterson, L. C: Climatically sensitive eolian and hemipelagic deposition in the Cariaco Basin, Venezuela, over the past 578000 years: Results from $\mathrm{Al} / \mathrm{Ti}$ and $\mathrm{K} / \mathrm{Al}$, Paleoceanography, 15, 210-228, doi:10.1029/1999PA900048, 2000.

Zhou, J. and Lau, K.-M.: Does a monsoon climate exist over South America?, J. Climate, 11, 1020-1040, 1998. 